\title{
Studies on Polymerization of Vinyl Chloride
}

\section{A Few Results Obtained from Copolymerization of Vinyl Chloride and Crotonic Acid Derivatives}

\author{
By Taizo Uno* and Keinosuke Yoshida*
}

\begin{abstract}
The copolymerization of vinyl chloride (VC) and crotonic acid derivatives was studied at $50^{\circ} \mathrm{C}$ in emulsion system, with potassium persulfate-sodium sulfite used as initiator. Derivatives are crotonic acid (I), ethyl crotonate (II), vinyl crotonate (III) and allyl crotonate. MRR is $r_{1}=2.4, r_{2}=0$ in (I), $r_{1}=2.0, r_{2}=0$ in (II) and $r_{1}=0.98, r_{2}=0.97$ in (III), respectively, Crotonyl group copolymerizes with VC to the same degree as vinyl acetate does with VC. Copolymers of VC-I and VC-II are soluble to aceton-methanol mixed solvent. There component copoly. merization of vinyl chloride-vinyl crotonate differs from vinyl chloride-vinyl acetate-crotonic acid system, and the former is restricted in the copolymerization prosses. The $k^{\prime}$ of Huggins at the gel point by cross-linking is 0.53 , and the chain transfer constant of crotonic acid is $2.1 \times 10^{-3}$.
\end{abstract}

第 12 報 過酸化クロトニルによる重合と分岐ポリマー

(1958 年 9 月 29 日受理)

宇野泰三・吉由経之助

\begin{abstract}
要旨過酸化クロトニル $(\mathrm{CPO})$ を開始剤として塊重合を $50^{\circ} \mathrm{C}$ で行なった。重合の促進作用は過酸

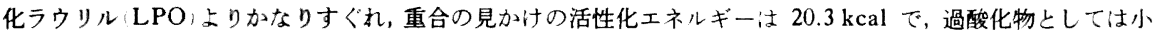
さい值である。CPO がモノマーに対して $1 / 400$ モル当量以上ではポリマーは不溶化し，以下では可溶である。 Huggins の $k^{\prime}$ は 0.4 1.8 で普通の重合開始鼡で得られるポリマーの0.3〜0.4に比べて大きいのは, 分岐 部分のポリマーが大きいため上考えられる。分岐によるゲル化点から $k^{\prime} 1.8$ を得た。橋かけによるゲル化点 の $k^{\prime}$ が 0.5 程度であるのと比へると興味がある。 $R_{p}$ は $[I]^{0.50}$ に比例する。
\end{abstract}

\section{1. 锗言}

脂肪族系の過酸化物で LPO 汶もっとも重合促准作用 が大きいといわれているが，不飽和結合をもった CPO はそれよりかなりすぐれていることがわかった。

CPO を開始郕とする場台は末端に共重合性のある2 重結合を持ったポリマーが生成する。VC はクロトニル 基とよく共重合するから分岐したポリマーが得られるは ずである。

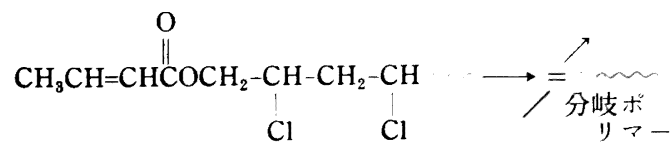

ポリマーの末端で共重合することは, CPOで重合させ たポリスチロールに酢酸ビニルを共重合させることがで きる゙から確実と考えられる。

VCのポリマーはモノマーに不溶であり，第 8 報 ${ }^{2)}$ 述べた重合機構から考えて，末端の共重合がいつ，どの
ように行なわれるかを知ること仗，逆に雨合機構を知る 上に興味がある。

一方 $\operatorname{Cotman}^{3)}$ によれば，普通 PVCはモノマー単位 50 - 100に1倜程度の分岐がある上報告されているが, Huggins の $k^{\prime}$ は $0.3 \sim 0.4$ 程度である。しかし CPO で 分岐ポリマーに寸ると $k^{\prime}$ は 0.4 1.8 のように大きな值 を示す。

このような二, 三の知見を得たので報壮する。

\section{2. 実験の”方法}

\section{1 過酸化物}

$\mathrm{CPO}$ は無水クロトン酸と過酸化バリウムの8 水塩を $0^{\circ} \mathrm{C}$ で 24 時間反応させた後エーテルで抽出,リグロイン から再結晶した。

LPO は市販品で純度 $97.2 \%$ であった

\section{2 重合方法}

すでに報告したディラトメーターで行なった。モ，マ 一は全部 $5 \mathrm{~g}$ ずつを用い, 重合辫は 60 。で此めた。 
第 1 表 $\mathrm{CPO}$ の濃度, 温度を変えた場合の $R_{p}$ 変化

\begin{tabular}{|c|c|c|c|c|c|}
\hline 記 & $\rightarrow$ & {$[I]_{\mathrm{CPO}} 4-50^{\circ}$} & {$[I]_{\mathrm{CPO}^{6-50^{\circ}}}$} & {$[I]_{\mathrm{CPO}} 12-50^{\circ}$} & {$[I]_{\mathrm{CPO}} 20-50^{\circ}$} \\
\hline \multicolumn{2}{|c|}{$[I] \cdot 10^{3}(\mathrm{~mol} / l)$} & 34.11 & 22.70 & 11.35 & 6.97 \\
\hline \multirow{3}{*}{$\begin{array}{l}R_{p} \cdot 10^{4} \\
(\mathrm{~mol} / l \cdot \mathrm{sec})\end{array}$} & 1 次 & 2.73 & 2.34 & 1.63 & 1.25 \\
\hline & 2 次 & 3.79 & 3.29 & 2.30 & 1.53 \\
\hline & 3 次 & 4.11 & 3.50 & 2.41 & 1.86 \\
\hline \multicolumn{6}{|c|}{ モノマーの Sp. Gr. $0.8722\left(40^{\circ}\right), 0.8514\left(50^{\circ}\right), 0.8307\left(60^{\circ}\right)$} \\
\hline
\end{tabular}

\begin{tabular}{c|c}
{$[I]_{\mathrm{CPO}} 6-40^{\circ}$} & {$[I]_{\mathrm{CPO}} 6-60^{\circ}$} \\
\hline 22.70 & 22.70 \\
\hline 0.78 & 5.82 \\
0.88 & 8.88 \\
1.13 & 8.88 \\
\hline
\end{tabular}

第 2 表 $\mathrm{CPO}$ の濃度と極限粘度, 重合度, $k^{\prime}$ の変化

\begin{tabular}{|c|c|c|c|c|c|c|c|c|}
\hline \multicolumn{2}{|c|}{ 記号 $\rightarrow[I]_{\mathrm{CPO}} 2-50^{\circ}$} & \multirow{2}{*}{$\frac{[I]_{\mathrm{CPO}^{4}}-50^{\circ}}{1 / 400}$} & \multirow{2}{*}{$\begin{array}{c}{[I]_{\mathrm{CPO}} 5-50^{\circ}} \\
1 / 500\end{array}$} & \multirow{2}{*}{$\frac{[I]_{\mathrm{CPO}^{7.5}-50^{\circ}}}{1 / 750}$} & \multicolumn{3}{|c|}{$[I]_{\mathrm{CPO}} 10-50^{\circ}[I]_{\mathrm{CPO}} 20-50^{\circ}[I]_{\mathrm{CPO}} 30-50^{\circ}$} & \multirow{2}{*}{ But. ald. +} \\
\hline $\begin{array}{l}\mathrm{CPO} / \mathrm{VC} \\
(モ ル 1)\end{array}$ & $1 / 200$ & & & & $1 / 1000$ & $1 / 2000$ & $1 / 3000$ & \\
\hline$\eta$ & 不 & 0.089 & 0.102 & 0.088 & 0.077 & 0.082 & 0.078 & 0.087 \\
\hline$k^{\prime}$ & 溶 & 1.824 & 0.773 & 0.522 & 0.370 & 0.292 & 0.407 & 0.245 \\
\hline $\bar{P}$ & & 1030 & 1285 & 1005 & 810 & 890 & 830 & 980 \\
\hline
\end{tabular}

\section{3 粘度測定}

Ubbelohde 型粘度計を用いシクロへキサノン溶液で 測定した。重合度は桜田ー松本の式から計算した。

\section{3. 重合の結果}

$\mathrm{CPO}$ の濃度および温度を変えた場合の結果を第 1 表 に，50ㄷ に扔ける $R_{p}$ と $[I]$ の両対数を第 1 図に示し to

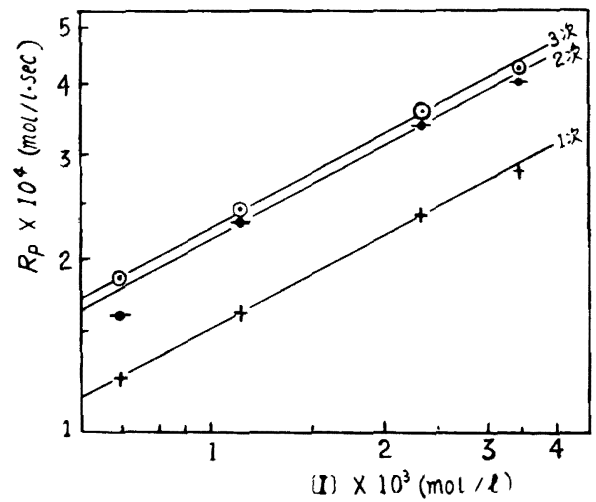

第 1 図過酸化クロトニルを開始剂とした場合 の $R_{p} \sim[I]$ の対数関係(第1 表より)

$R_{p}$ は $[I]^{0.56}$ に比例し, 重合の見かけの活性化ェネル

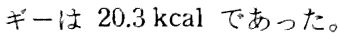

第2四はLPO在用いた場合と重合速度の比較であ る。
第 2 表は CPO の濃度を変えた場合の極限粘度, 重合 度, $k^{\prime}$ である。極限粘度は大きな相違が認められないが， k'はかなり変化する。第 3 図に粘度勾配を示した。

\section{4.}

\section{$4.1 \mathrm{CPO}$ の重合促進作用}

LPO に比べてかなり重合促進作用の大きいことが第 2 図から明らかである。重合の見かけの活性化エネルギ 一は過酸化物の分解の活性化エネルギーを表わしている

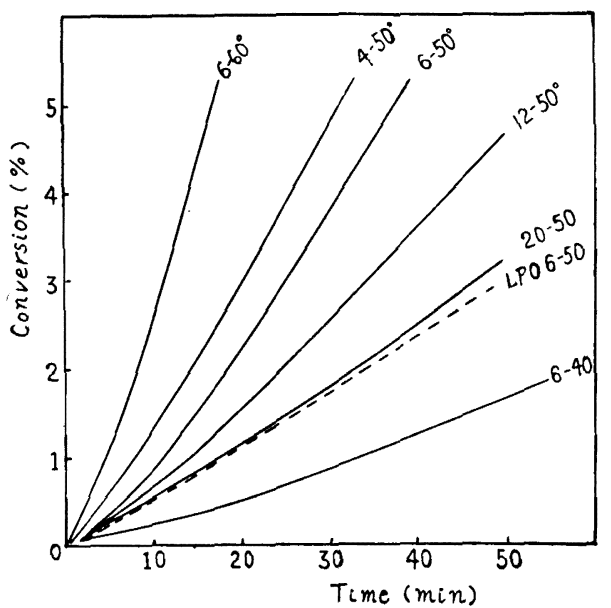

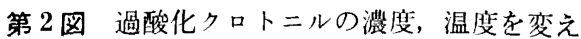
た場合および過酸化ラウリルを用いた場合の Time-Conversion Curve 


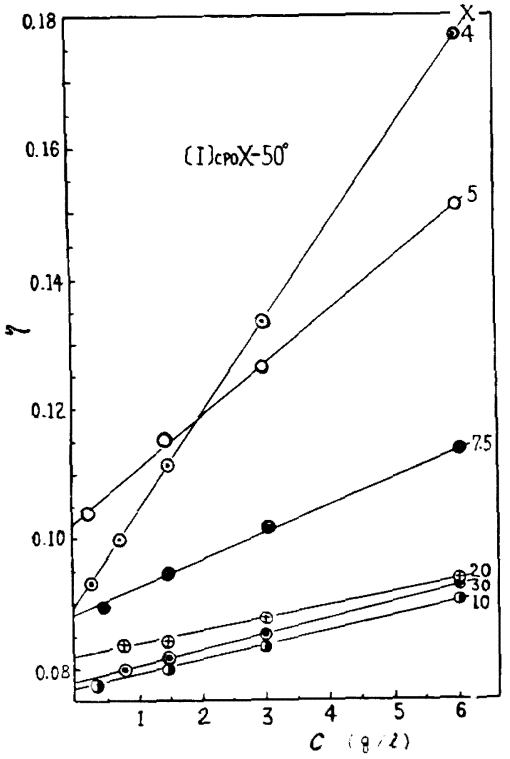

第 3 図過酸化クロトニルの濃度を変えた場合 の粘度勾配 (第 2 表参照)

と考えても大した違いはないが，一般に $30 \mathrm{kcal}$ 程度を 示すよらである。しかし，CPO の場合位 $20 \mathrm{kcal}$ でか なり分解しやすいといえる。

\section{2 分岐と重合機構}

Cotman によれば普通の PVC は 50 100モノマー単 位に 1 個の割合で分岐があると報告されているが，重合 の方法および重合率を変えて Huggins の $k^{\prime}$ を調べた5 が 0.3〜0.4であった。特に重合率を $90 \%$ 程度にした場 合も同様であった。

しかし分岐をできるだけ少なくするために，重合系に ブチルアルデヒドを添加していろいろ重合度の異なるポ リマーをつくり"， $k^{\prime}$ を比べると 0.3 以下のものが多 かった。第 2 表の右端はアルデヒドを添加した場合の中 で CPO から得たポリマーと重合度の比較的近似したも のを比較に記载した。

一方, CPO で分岐させた場合, 開始剂濃度で異なるが 0.4 1.8 となり非常に大きな值であった。大きな分岐の あるポリマーは重合度式が当然異なってくると考えられ るが，極限粘度を直接使って重合度式から重合度を求め ると，第 2 表のよ5に分岐によって 20 〜 $30 \%$ 程度大き くなっているだけで，極端に大きな重合度增加も示して いないことがわかった。 $P$ は $[I]^{8}$ に反比例することを 他の開始剤采(6) で見出されているから，末端つクロトニ ル濃度注 $[I]^{\mathrm{z}}$ に比例して增加するにすぎないことが考 えられる。したがって，[I] を 1/400 から 1/3000モル 当量モノマーの籁囲で変えても，末端のクロトニル嶩度
が大きく変化することはない。さらにクロトニル基が全 部共重合するとは限らないから，末端基共重合による分 岐で，重合度の增加が 20 ３0\% 程度であることはらな ずける。しかし KPS やアゾビスイソブチロニトリルを 開始郕とした場合でも，重合率が $80 \%$ 近くになると初 期に比べて重合度は 20 - 30\% 増加するが， $k^{\prime}$ は 0.4 程 度である5”。それに比べて CPO を開始剤とする場合の 的の増加はかなり大きい。これは共重合により分岐した ポリマーがかなり大きいことを推定させる。

以上のことを要約すると, 連鎖移動によって生成した 分岐部分のポリマーとポリマーの末端で共重合して生成 した分岐を比べて，後者の方が大きいことが考えられる。 VC のポリマー粒子はモノマーに不溶であるが，モ， マーが自由に通れる程度にポーラスである21。CPO で重 合したポリマーはその開始側の末端にクロトニル基をも っているが，ポリマー粓子の内部は十分にモノマーを含 有しているから粓子の内部で重合が続けられ，当然共重 合も起りうると考えられる。共重合したポリマーは次の ような形をもっているだろう。

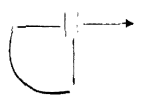

(a)<smiles>CI1CC1</smiles>

(b)

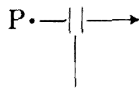

(c) （a）は同一ポリマーで輪状に共重合した場合，(b)は連 鎖移動したモ/マーラジカル $(\mathrm{M} \cdot)$ が粒子内で再開始し で，そのポリマーラジカルによって分岐した場合，(c) は他のポリマーラジカルが粒子内に入ってきて分岐した 場合である。それぞれの割合などは決める手段がない が，(c)の場合は特に大きな分岐が起っていると考えら れる。

連鎖移動によって生成した分岐ポリマーが小さいだろ うと述へたのは，ポリマーとの連鎖移動が多くなるのは ポリマー濃度が大きくなった場合で，分岐ポリマーラジ カルが生成しても，連鎖移動しやすいポリマー ${ }^{5)}$ の濃度 が大きくなっているから，分岐ポリマーラジカルがあま り成長しないらちに再び連鎖移動する。したがって分岐 部分のポリマーは小さいと考えら礼る。

\section{5. 結論}

$\mathrm{CPO}$ は LPO より分解しやすく, 重合開始剂としては すぐれている。

CPO で重合させたポリマーの末端基は共重合して分 岐ポリマーを生成するが, 分岐部分のポリマーは大きく， Huggins の $k^{\prime}$ も著しく大きくなる。

しかし普通の開始郕で重合させたポリマーが重合の進 行とともに速鎖移動によって分岐した場合，分岐部分の ポリマー住前者に比べて小さいと考えられ， $k^{\prime}$ もまど に大きくはならない。 
分岐部分の長さの大きな場合は $k^{\prime}$ も大きく, 小さな場 合は $k^{\prime}$ あまり大きくならないことが考えられる。 分岐重合における停止は 2 分子停止であった。

文献

1) 宇野, 永井, 吉田：日化第 9 年会で講演

2) 宇野: 高化投稿中

3）原報は J. D. Cotman：Annals of the New York Academy of Science 57, Art. 4, 417; G. Bier und
H. Krämer：Kunststoffe, 46, 504(1956)に引用され ている。

4) 宇野, 古田：日化第 8 年会で一部を講演

5) 宇野, 吉田：続いて投稿する予定

6) 宇野, 吉田：高化, 14, 602(1957) 水溶液重合加ら 渡辺, 豊田, 天城：高分子討論会 $(1957$, 於名大) メ夕 ノール中の重合から

7） 2)では検討しなかったが重合場所を参考として考え た。

\title{
Studies on Polymerization of Vinyl Chloride \\ XII. On Polymerization using Crotonyl Peroxide and Branched Polymer
}

\author{
By Taizo Uno* and Keinosuke Yoshida*
}

\begin{abstract}
Using crotonyl peroxide (CPO) as initiator, bulk polymerization at $50^{\circ} \mathrm{C}$ was studied. The catalytic action is more excellent than lauroyl peroxide. Apparrent activation energy of polymerization is $20.4 \mathrm{kcal} / \mathrm{mol}$, which is small for peroxide. If the CPO concentration is above $1 / 400$ eq. mol per monomer, insoluble polymer is obtained, and if the CPO concentration is below it, polymer obtained is soluble in a solvent. The $k^{\prime}$ of Huggins is 0.4 $\sim 1.8$, which is larger than ordinary polymer, $0.3 \sim 0.4$. It is obvious, therefore, that the branching part of polymer is large. The $k^{\prime}$ of Huggins at the gel point by branching was 1.82. Compared with the $k^{\prime}$ of the gel point by cross-linking is 0.5 , it is interesting. The rate of polymerization is proportional to $[I]^{0.56}$.
\end{abstract}

* The Osıka Municipal Technical Research Institute (Kitaogi-machi, Kitaku Osaka) 